\title{
REFORMING TO PRESERVE: COMPSTAT AND STRATEGIC PROBLEM SOLVING IN AMERICAN POLICING*
}

\section{DAVID WEISBURD}

Hebrew University and University of Maryland-College Park

\section{STEPHEN D. MASTROFSKI}

George Mason University

ANN MARIE MCNALLY

Police Foundation

\section{ROSANN GREENSPAN}

University of California-Berkeley

\section{JAMES J. WILLIS \\ University of Massachussetts-Boston}

\section{Research Summary:}

This paper provides the first national description of Compstat programs, considered in the framework of strategic problem solving. Relying on a survey of American police departments conducted by the Police Foundation, we examine the diffusion of Compstat programs and the nature of Compstat models throughout the United States. We also assess the penetration of models of strategic problem solving more generally into American policing. Our findings document a process of "diffusion of innovation" of Compstat-like programs in larger police agencies that follows a rapid pace. At the same time, our data suggest that many elements of strategic problem solving had begun to be implemented more widely across American police agencies before the emergence of Compstat as a programmatic entity, and that such elements

* This research was supported by Grant 98 -IJ-CX-0070 from the National Institute of Justice to the Police Foundation. The opinions and positions expressed in this paper are those of the authors. We would like to thank Frank Gajewski, Thomas Frasier, Scott Keeter, Lorraine Green Mazerolle, Ed Maguire, Roger Parks, Richard Ritti, Eli Silverman, and Chris Tutko for their thoughtful advice in constructing our survey. We also owe a special debt to Ed Maguire for his assistance in selecting the study sample, and George Kelling, Phyllis McDonald, and Richard Ritti for their insights regarding Compstat as a police reform. We would also like to thank Cynthia Lum, Michelle Manspeizer, Laura Wyckoff, and Sue-Ming Yang for their help in preparation of the final manuscript.

$\begin{array}{llll}\text { VOLUME } 2 & \text { NUMBER } 3 & 2003 & \text { PP 421-456 }\end{array}$


have been adopted broadly even by departments that have not formally adopted a Compstat program.

\section{Policy Implications:}

Compstat holds out the promise of allowing police agencies to adopt innovative technologies and problem-solving techniques while empowering traditional police organizational structures. However, our analysis suggests that at this stage, what most characterizes Compstat departments and distinguishes them from others is the development of the control element of this reform. This leads us to question whether the rapid rise of Compstat in American police agencies can be interpreted more as an effort to maintain and reinforce the "bureaucratic" or "paramilitary" model of police organization (that has been under attack by scholars for most of the last two decades) than as an attempt to truly reform models of American policing.

KEYWORDS: Policing, Compstat, Problem Solving, Diffusion of Innovation, Police Organization

Reform, that you may preserve. - Lord Macaulay, 1831.

If we want everything to remain the same, then everything is going to have to change. - Giuseppe di Lampedusa, 1958.

Introduced as recently as 1994 by then Commissioner William Bratton of the New York City police department, Compstat has already been recognized as a major innovation in American policing. In the few years since its appearance, it has been reported that police departments around the country have begun to adopt Compstat or variations of it (Law Enforcement News, 1997; Maas, 1998; McDonald, 2001). In turn, the program has received national publicity (including awards from Harvard University and former Vice President Al Gore) and has been credited by its originators and proponents with impressive reductions in crime and improvements in neighborhood quality of life in New York City. Other cities, such as violence-plagued New Orleans, have reported success with their versions of Compstat (Gurwitt, 1998; Remnick, 1997), and agencies from around the nation and the world are flocking to New York City to learn more about the program (Maas, 1998).

The attention shown this reform indicates it may become the twentyfirst century ideal of what it means to be a progressively managed department, much as Theodore Roosevelt's "good government" approach to policing did a century ago (Berman, 1987). As with Roosevelt's reforms, Compstat did not emerge full-blown and unprecedented in New York City. Commissioner Bratton and his staff drew heavily on management 
principles that had already received acclaim as state-of-the-art and forward-looking (Bratton, 1998; Micklethwait and Wooldridge, 1996; Simons, 1995). These principles included developing a management commitment and capacity to (1) clarify the agency's mission by focusing on its basic values and embodying them in tangible objectives, (2) give priority to operational objectives over administrative ones, (3) simplify managerial accountability for achieving those objectives, (4) become more adept at scanning the organization's environment to identify problems early and develop strategies to respond (e.g., being "data-driven"), (5) increase organizational flexibility to implement the most promising strategies, and (6) learn about what works and what does not by following through with empirical assessment of what happened. These, among other features of management style, have come to be characterized as "strategic leadership" and "strategic choice" (Beer, 1980:45; Finkelstein and Hambrick, 1996).

Elements of strategic leadership date back to Philip Selznick (1957), but they received tremendous attention in the United States in the 1980s, when organizational development leaders made them bywords of progressive management in the private sector (Micklethwait and Wooldridge, 1996). Since then, elements of this approach have been introduced to government agencies in general (Osborne and Gaebler, 1992), and to the police in particular under the rubric of problem-oriented policing (Goldstein, 1990). Compstat brings many of these management prescriptions together in a single program customized for police organizations. We characterize this approach more generically as "strategic problem solving." "Strategic" is an apropos descriptive because it highlights the thrust of this reform to establish a big-picture approach to police management's need to deal with an uncertain and unstable environment.

This paper provides the first national description of Compstat programs, considered in the framework of strategic problem solving. Relying on a survey of American police departments conducted by the Police Foundation, we examine the diffusion of Compstat programs and the nature of Compstat models throughout the United States. We also assess the penetration of models of strategic problem solving more generally into American policing. Our findings document a process of "diffusion of innovation" (see Rogers, 1995) of Compstat-like programs in larger police agencies that follows a rapid pace. At the same time, our data suggest that many elements of strategic problem solving had begun to be implemented more widely across American police agencies before the emergence of Compstat as a programmatic entity, and that such elements have been adopted broadly even by departments that have not formally adopted a Compstat program.

To understand the rapid diffusion of Compstat-like programs in large police agencies in the United States, we will argue that this innovation 
should be seen less as a revolution in American policing than as an evolution of principles that have been developing on the American police scene over the last two decades. However, the fact that many of the components of Compstat were being implemented in police agencies as part of a more general trend toward strategic problem solving is not enough in our view to explain the rapid adoption of Compstat programs that we document in our paper. Nor is the much touted, although largely undocumented, promise of Compstat as a crime-prevention tool (Bouza, 1997; Eck and Maguire, 2000; Witkin, 1998) sufficient as an explanation for its extraordinarily rapid diffusion among contemporary police organizations in the United States (Crank and Langworthy, 1992; Manning, 1997; Mastrofski, 1998). We show in our paper that specific components of this innovation that reinforce traditional hierarchical structures of police organization have taken a predominant role in the implementation of Compstat-like programs nationally. This leads us to question whether the rapid rise of Compstat in American police agencies can be interpreted more as an effort to maintain and reinforce the "bureaucratic" or "paramilitary" model of police organization (see Bittner, 1980; Goldstein, 1977; Punch, 1983) that has been under attack by scholars for most of the last two decades (Goldstein, 1990; Greene and Mastrofski, 1988; Mastrofski, 1998; Skolnick and Bayley, 1986; Weisburd et al., 1988) than as an attempt to truly reform models of American policing.

We begin our paper by describing the emergence of Compstat in New York City and defining core elements of the Compstat model. We then describe our study and findings and conclude with a discussion of their implications.

\section{COMPSTAT AND ORGANIZATIONAL CHANGE: HISTORY AND CORE ELEMENTS}

The Compstat idea emerged as a new administration took office in New York City, promising to control crime and disorder. Viewed in a broader context, the shape of organizational reform derived from several sources. First are the failures, both perceived and documented, of "traditional" policing (Fogelson, 1977; Goldstein, 1990; Kelling and Moore, 1988; Weisburd and Braga, 2003): entrenched bureaucracies that focused more on administration than real performance, rising crime rates, increasing fear of crime, studies showing that traditional reactive enforcement approaches had no effect on crime, and competition from the private sector in the form of corporation-provided security services. In this context, as Mark Moore has written; "Commissioner Bratton's bold statement-reacceptance of responsibility for controlling crime - was a very important moment in leadership of the criminal justice system" (1997:67). Second is 
the ambiguity of setting priorities under community policing programs, and especially the challenge of finding ways to harness the diffuse forces that pressure a police agency once it commits to decentralizing decision making, increasing the participation of the rank-and-file, and encouraging community input in setting priorities and partnership strategies with the police (Mastrofski, 1998).

On the positive side, four rapidly growing and interrelated trends made strategic problem solving in the context of Compstat both appealing to police leaders and feasible to implement. First among these is problemoriented policing (Goldstein, 1990), an approach that, above all, stresses the importance of data-driven decision making about what to do. A second trend is the growth in knowledge about crime and effective responses to crime (Braga, 2001; Sherman, 1990; Sherman and Weisburd, 1995; Sherman et al., 1997). A third trend is the ready availability of rapidly growing technology in computers, data management and analysis, geographic information systems, and communications-all of which make it possible to process large amounts of information and disseminate it to diverse users on a timely basis (Anselin et al., 2000; Weisburd and McEwen, 1997). Finally, police leaders have become increasingly open to the prescriptions of progressive management, communicated to them by consultants, trainers, and contractors outside policing who apply the most recent terms, methods, and approaches to strategic management developed for corporations in the private sector (Klockars and Harver, 1993; Micklethwait and Wooldridge, 1996). These positive and negative trends have attracted and driven police leaders toward an increasingly accepting view of strategic problem solving.

A review of the emergence of Compstat in New York helps us understand what Compstat is and why it emerged there. The particulars of Compstat's origins have been described in considerable detail elsewhere (Bratton, 1998; Kelling and Coles, 1996; Maple, 1999; McDonald et al., 2001; Silverman, 1999). The impetus behind Compstat was Commissioner Bratton's intention to make a huge organization, legendary for its resistance to change (Sayre and Kaufman, 1960), responsive to his leadership, a leadership that had clearly staked out crime reduction and improving the quality of life in the neighborhoods of New York City as its top priorities (Bratton, 1999). Based on his belief in principles of strategic leadership and his own experiences with the Boston Police Department and the New York City Transit Police, Bratton and his lieutenants set out to disprove skeptics who claimed that the police can do little about crime and disorder.

At the outset, Bratton and his administration's analysis of NYPD's problems revealed several deficiencies that have long been identified as forms of bureaucratic dysfunction (Merton, 1940). First, the organization 
lacked a sense of the importance of its fundamental crime control mission. Second, NYPD was not setting high enough expectations about what its officers could do and accomplish; consequently, a lot less was getting done than was possible. Third, too many police managers had become moribund, content to continue doing things the way they had always been done, rather than searching for better ways to accomplish results. The police were not taking advantage of new theories and studies that highlighted promising strategies to reduce crime and improve the quality of life in neighborhoods. Fourth, the department was beset with archaic, unproductive organizational structures that did more to promote red tape and turf battles than to facilitate teamwork to use scarce resources effectively; operational commanders were "handcuffed" by headquarters, lacking authority to customize crime control to their precinct's needs. Finally, the department was "flying blind"; it lacked timely, accurate information about crime and public safety problems as they were emerging; it had little capacity to identify crime patterns; and it had difficulty tracking how its own resources were being used. And middle managers were not in the habit of monitoring these phenomena, thus serving as a weak link in the chain of internal accountability between top brass and street-level police employees.

Bratton used a "textbook" approach to deal with these problems, following the major prescriptions offered by organizational development experts to accomplish organizational change (Beer, 1980). He brought in outsiders to obtain a candid diagnosis of the organization's strengths and weaknesses. He incorporated both top-down and bottom-up processes to implement change (Silverman, 1996). He sought and obtained early indicators of the success of the change efforts, and he sought ways to reinforce the individual efforts of his precinct commanders and the rank-andfile, by using both incentives and disincentives (Bratton, 1996).

Strictly speaking, Compstat refers to a "strategic control system" developed to gather and disseminate information on NYPD's crime problems and track efforts to deal with them. As such, it addresses the problem of inadequate information described above, and in this sense, it is a structure intended to serve the implementation of NYPD's Crime Control and Quality of Life Strategies (Office of Management Analysis and Planning, Updated:1). But it has become shorthand for the full range of strategic problem solving in the department. These elements of NYPD's Compstat approach are most visibly displayed in the twice-weekly Compstat "Crime Control Strategy Meetings," during which precinct commanders appear before several of the department's top brass to report on crime problems in their precincts and what they are doing about them.

This occurs in a data-saturated environment in which Compstat reports play a central role. Precinct crime statistics and other information about 
the precinct and its problems are projected onto overhead screens, and commanders respond to queries about what they are doing to deal with those problems. Crime data that were once three to six months late are now available to precinct commanders on a weekly basis for the past week. The report includes weekly, monthly, and annual tallies of crime complaints, arrests, summonses, shooting incidents, and victims, organized by precinct, borough, and citywide. In addition, electronic pin maps are generated to show how crimes and police activities cluster geographically. Hour-of-the day analyses and "crime spike" analyses are also carried out. In addition, the precinct commander's background is profiled, as well as other features of the precinct under his or her command (e.g., demographic data, workload data, and various activities).

Compstat reports serve as the database for commanders to demonstrate their understanding of the crime problems in their areas and discuss future strategies with the top brass and other commanders present. Cross-unit coordination is planned, if necessary, and all of the plans are thoroughly documented. When the precinct is reselected for participation in a Compstat meeting, the commander must demonstrate that he or she has followed up on these strategies. Sometimes commanders bring subordinates with them so that they can report on their efforts and receive recognition. The press and other outside agencies are sometimes invited to attend these sessions, with as many as 200 people in attendance, thus providing "great theater," and developing in the public a greater awareness of how the department is being managed (Bratton, 1998:296).

But there is far more to Compstat than this (Giuliani and Safir, 1998; Gurwitt, 1998). Drawing from what those who developed Compstat have written (see Bratton, 1996, 1998, 1999; Maple, 1999) as well as what those who have studied Compstat have observed (see Kelling and Coles, 1996; McDonald et al., 2001; Silverman, 1999), we identify six key elements that have emerged as central to the development of strategic problem solving in Compstat programs: mission clarification, internal accountability, geographic organization of command, organizational flexibility, data-driven problem identification and assessment, and innovative problem solving. Together they form a comprehensive approach for mobilizing police agencies to identify, analyze, and solve public safety problems.

\section{MISSION CLARIFICATION}

Compstat assumes that police agencies, like military organizations, must have a clearly defined organizational mission in order to function effectively. Top management is responsible for clarifying and exalting the core features of the department's mission that serve as the overarching reason for the organization's existence. Mission clarification includes a demonstration of management's commitment to specific goals for which the 
organization and its leaders can be held accountable, such as reducing crime by $10 \%$ in a year (Bratton, 1998).

\section{INTERNAL ACCOUNTABILITY}

Internal accountability must be established so that people in the organization are held directly responsible for carrying out organizational goals. Compstat meetings in which operational commanders are held accountable for knowing their commands, being well acquainted with the problems in the command, and accomplishing measurable results in reducing those problems, or at least demonstrating a diligent effort to learn from the experience, form the most visible component of this accountability system. However, such meetings are part of a more general approach in which police managers are held accountable and can expect consequences if they are not knowledgeable about or have not responded to problems that fit within the mission of the department. "Nobody ever got in trouble because crime numbers on their watch went up. I designed the process knowing that an organization as large as the NYPD never gets to Nirvana. Trouble arose only if the commanders didn't know why the numbers were up or didn't have a plan to address the problems" (Maple, 1999:33). Internal accountability in Compstat establishes middle managers as the central actors in carrying out the organizational mission, and it holds them accountable for the actions of their subordinates.

\section{GEOGRAPHIC ORGANIZATION OF OPERATIONAL COMMAND}

Although Compstat holds police managers to a high level of accountability, it also gives commanders the authority to carry out the agency's mission. Organizational power is shifted to the commanders of geographic units. Operational command is focused on the policing of territories, so central decision-making authority on police operations is delegated to commanders with territorial responsibility (e.g., precincts). Functionally differentiated units and specialists (e.g., patrol, community police officers, detectives, narcotics, vice, juvenile, traffic, etc.) are placed under the command of the precinct commander, or arrangements are made to facilitate their responsiveness to the commander's needs. Silverman notes that in New York, "Rather than allow headquarters to determine staffing and deployment on a citywide basis, it was decided that reducing crime, fear of crime, and disorder would flow from patrol borough and precinct coordination of selected enforcement efforts" (1999:85).

\section{ORGANIZATIONAL FLEXIBILITY}

Middle managers are not only empowered with the authority to make 
decisions in responding to problems, but they are also provided with the resources necessary to be successful in their efforts. Compstat requires that the organization develop the capacity and the habit of changing established routines to mobilize resources when and where they are needed for strategic application. For example, in New York City, "Commanding officers (COs) were authorized to allow their anticrime units to perform decoy operations, a function that had previously been left to the Citywide Street Crime Unit. Precinct personnel were permitted to execute felony arrests warrants, and COs could use plainclothes officers for vice enforcement activities. Patrol cops were encouraged to make drug arrests and to enforce quality-of-life laws" (Silverman, 1999:85).

\section{DATA-DRIVEN PROBLEM IDENTIFICATION AND ASSESSMENT}

Compstat requires that data are made available to identify and analyze problems and to track and assess the department's response. Data are made available to all relevant personnel on a timely basis and in a readily usable format. According to Maple, "We needed to gather crime numbers for every precinct daily, not once every six months, to spot problems early. We needed to map the crimes daily too, so we could identify hot spots, patterns, and trends and analyze their underlying causes" (Maple, 1999:32).

\section{INNOVATIVE PROBLEM-SOLVING TACTICS}

In our discussion of strategic problem solving, we identified the importance of problem-solving models in the development of Compstat. Middle managers are expected to select responses because they offer the best prospects of success, not because they are "what we have always done." Innovation and experimentation are encouraged; use of "best available knowledge" about practices is expected. In this context, police are expected to look beyond their own experiences by drawing on knowledge gained in other departments and from innovations in theory and research about crime prevention.

These six key elements constitute the core of organization development prescriptions associated with Compstat. Although there is much anecdotal evidence of the adoption of Compstat models by American police agencies outside New York, there has been little systematic examination of whether and to what extent departments are implementing the various elements of Compstat. It is also unclear whether the adoption of Compstat truly represents a radical departure from models of policing that are carried out in departments that have not adopted the Compstat model. Our study seeks 
to address these core concerns in understanding the diffusion and implementation of Compstat programs.

\section{THE DIFFUSION OF COMPSTAT-LIKE PROGRAMS}

Our data are drawn from a survey of a stratified sample of American police agencies with municipal policing responsibilities conducting by the Police Foundation (see Weisburd et al., 2001). The mail survey was sent to all such police agencies with over 100 sworn police officers and to a random sample of 100 agencies with 50 to 99 sworn officers. We surveyed the universe of larger departments because Compstat programs were seen to be more relevant to and feasible in such agencies, but we also drew a random sample of smaller departments in order to identify whether Compstat programs were an appreciable factor for them.

The sample was drawn from the most complete listing of American police agencies in 1999, the 1996 Directory Survey of Law Enforcement Agencies conducted by the Bureau of Justice Statistics (BJS) and the Census Bureau (Bureau of Justice Statistics, 1998). There were 515 agencies with 100 or more sworn officers, and 698 agencies with 50 to 99 officers. Surveys were mailed in August 1999, and the last completed survey was received in January 2000 . Overall, $86 \%$ of the departments we selected sent responses back to the Police Foundation. ${ }^{1}$ The characteristics of our survey sample follow closely national characteristics of departments in terms of geographic distribution and size (see Weisburd et al., 2001). In this paper, we report primarily on the survey findings, but we also draw on observations made during 15 two- to three-day site visits to Compstat programs, and three on-site observations of model Compstat programs, each taking several months (see Greenspan et al., 2003; Willis et al., 2003).

\section{SELF-REPORTED ADOPTION OF COMPSTAT PROGRAMS}

The survey presented police agencies with a listing of "features that have been associated with Compstat and similar programs." 2 We then asked whether their department had already implemented or was planning to implement a "Compstat-like program." A third of the departments in the sample of agencies with 100 or more sworn officers reported that they had implemented a "Compstat-like program."3 An additional quarter of

1. Response rates were similar for the survey of large departments $(86 \%)$ and the small department sample $(85 \%)$.

2. For each "feature," we also asked if and for how long "the department has been doing this."

3. One reviewer of our paper suggested that the claimed implementation of a Compstat-like program was likely to be overstated in our survey because police executives and ranking police managers-those who were most likely to fill out this part of the survey-would want their agency to be seen as cutting edge. (In more than half of 


\section{FIGURE 1. REPORTED YEAR OF ADOPTION OF A COMPSTAT PROGRAM}

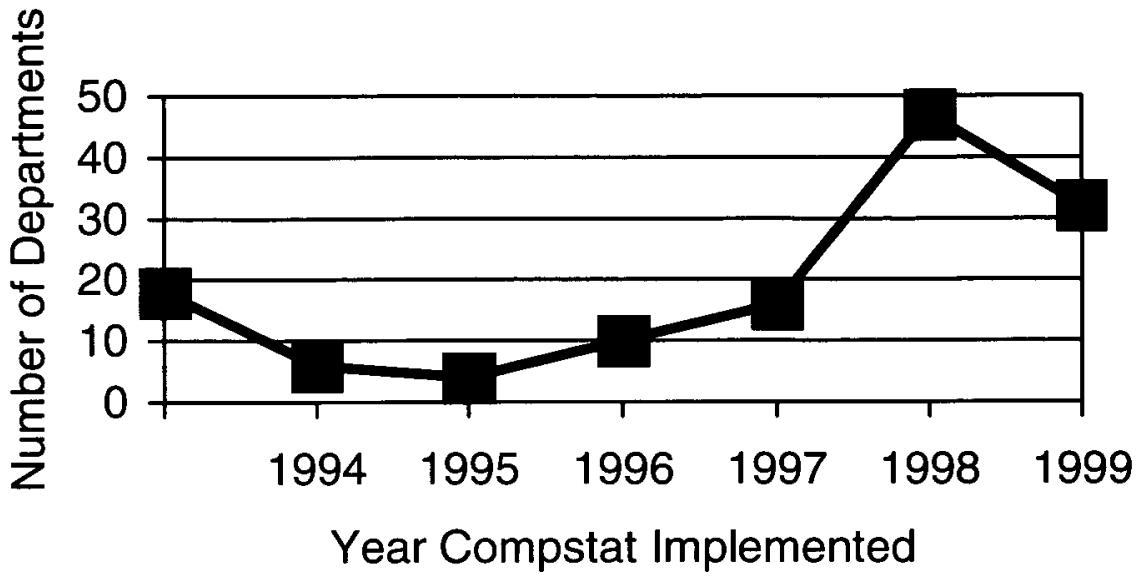

these departments claimed to be planning such a program. Although not evenly distributed across the nation's regions, there was sufficient distribution among large departments to say that Compstat enjoys widespread interest across the country ( $42 \%$ of departments in the South, $32 \%$ in the West, $27 \%$ in the Northeast, and $22 \%$ in the North Central regions). As expected, departments in the small agency sample were much less likely to report having adopted a Compstat model. Although about $30 \%$ of these departments claimed to be planning to implement a Compstat-like program, only $9(11 \%)$ had already done so at the time of the survey. Because the number of adoptors here is very small, we focus our statistical analyses and discussion below only on responses from the survey of police agencies with 100 or more sworn officers.

We also asked departments when their Compstat or Compstat-like program was implemented. Figure 1 shows that the large growth in implementation of Compstat programs in larger police agencies occurred a few years after New York's program had begun to gain wide-scale publicity, between 1997 and 1998. The downward trend in 1999 is likely an artifact of the timing of the survey, which was sent to respondents in August 1999

the surveys, the chief executive of the police organization claimed to answer this series of questions, whereas in the bulk of the remaining cases, another high-ranking police executive or an assistant to the chief executive responded). As we promised complete confidentiality for the departments in our survey, we suspect that the motivation to make the departments look good would likely not have been an important factor. Moreover, in each of the 15 cases where we conducted site visits, survey responses were generally consistent with our observations. 


\section{TABLE 1. PERCENT OF DEPARTMENTS THAT CLAIMED TO IMPLEMENT SPECIFIC FEATURES OF COMPSTAT BEFORE 1994}

\begin{tabular}{ll}
\hline Survey Item & $\%$ Yes \\
\hline $\begin{array}{l}\text { Set specific objectives in terms that can be precisely measured }(\mathrm{n}=407) \\
\text { Hold regularly scheduled meetings with district commanders to review progress } \\
\quad \text { toward objectives }(\mathrm{n}=415)\end{array}$ & $26.0 \%$ \\
$\begin{array}{l}\text { Hold middle managers responsible for understanding crime patterns and } \\
\text { initiating plans to deal with them }(\mathrm{n}=409)\end{array}$ & $26.3 \%$ \\
$\begin{array}{l}\text { Give middle managers control over more resources to accomplish objectives } \\
\quad(\mathrm{n}=412)\end{array}$ & $22.7 \%$ \\
$\begin{array}{l}\text { Use data to assess progress toward objectives }(\mathrm{n}=414) \\
\text { Develop, modify or discard problem solving strategies based on what the data } \\
\text { show }(\mathrm{n}=411)\end{array}$ & $23.1 \%$ \\
\hline
\end{tabular}

and thus generally provided data on implementation for less than the complete year.

Eighteen departments in our large agency sample report implementation before 1994-the year NYPD introduced Compstat. This suggests that a few police agencies in our survey thought that they had fully implemented the key elements of strategic problem solving before New York had coined the term Compstat. Moreover, many other departments reported that they had implemented specific elements of Compstat before New York City's model had become prominent (see Table 1). For example, about a quarter of departments with 100 or more sworn officers claimed to have "set specific objectives in terms that can be precisely measured" or to have held "regularly scheduled meetings with district commanders to review progress toward objectives" at least six years before the survey, a time that predates the creation of Compstat in New York City.

Whether or not police agencies around the nation anticipated the emergence of Compstat, New York has clearly led the way in promoting its dissemination. Seventy-two departments reported visiting New York to observe Compstat, whereas the next three most frequently visited departments mentioned had 12,9 , and 2 visitors, respectively. Virtually all departments with more than 500 sworn that had implemented Compstat also reported that they were "very or somewhat familiar" with NYPD's version, and $90 \%$ of those that had not implemented Compstat reported the same. Among the agencies in the 100 to 299 officer range, $73 \%$ of the Compstat implementers said they were very or somewhat familiar with NYPD's Compstat, and fully $55 \%$ of the nonimplementers reported the same.

Our survey shows that larger American police agencies claim to have adopted Compstat at a high rate and very rapidly. How does this compare 
with the adoption of other social or technological innovations? In recent years, there has been growing interest in the analysis of innovation, which has been found to have a fairly consistent form, called the " $s$ " curve of innovation (Rogers, 1995). The $s$ curve is developed by measuring the cumulative adoption of an innovation over time. In Figure $2 \mathrm{~A}$, the innovation adoption curve for Compstat-like programs in police agencies with over 100 sworn officers is presented.

Can we argue from this that the diffusion of Compstat-like programs suggests a rapid rate of innovation? Arnulf Grübler (1991) provides a yardstick. He analyzes two samples of technologies, including such areas as energy, transport, communication, agriculture, military technologies, as well as some social changes such as literacy, in the United States for which data on diffusion of innovation were available. He constructs a measure, delta $t$, which is the time period it takes for an innovation to go from $10 \%$ to $90 \%$ of its saturation or highest level of adoption. He finds that between $13 \%$ and $25 \%$ of different types of technology progress from $10 \%$ to $90 \%$ of their saturation level within 15 years. Another $25 \%$ to $30 \%$ of his samples reached this saturation level in 30 years.

It is not possible to calculate delta $t$ precisely for the adoption of Compstat-like programs before the saturation process is complete. However, we can estimate the cumulative adoption curve using the data available from our survey. Rogers notes that the adoption of an innovation generally "follows a normal bell-shaped curve" when plotted over time as a frequency distribution (Rogers, 1995:257). In Figure 2B, we develop a cumulative adoption curve based on this assumption extrapolating from our observed data. ${ }^{4}$ Based on this distribution and allowing saturation to include all police departments in our sample, we estimate a $90 \%$ saturation level between 2006 and 2007. As 10\% saturation using the observed data was defined as occurring between 1996 and 1997, our estimate of delta $t$ is about 10 years. Accordingly, if the adoption of Compstat-like programs was to follow the growth patterns observed in our data, Compstat would rank among the most quickly diffused forms of innovation.

4. In estimating the normal frequency distribution on which the $s$ curve is based, we relied upon the observed data between 1995 and 1998. We excluded the 1999 year because of the timing of the survey, which likely underrepresented the number of adoptions. We also excluded years before 1995, because the number of cases were relatively small and likely to lead to unstable estimates. In developing an estimated value for the standard deviation unit of the normal curve, we compared each year's frequency between 1995 and 1998 and then took the average estimate gained. After defining the normal frequency distribution, we then converted the estimates to a cumulative distribution curve. 


\section{FIGURE 2. CUMULATIVE ADOPTION CURVES FOR COMPSTAT PROGRAMS (ACTUAL AND EXTRAPOLATED)}

\section{A. Actual Cumulative Adoption Curve Based on Survey Findings}

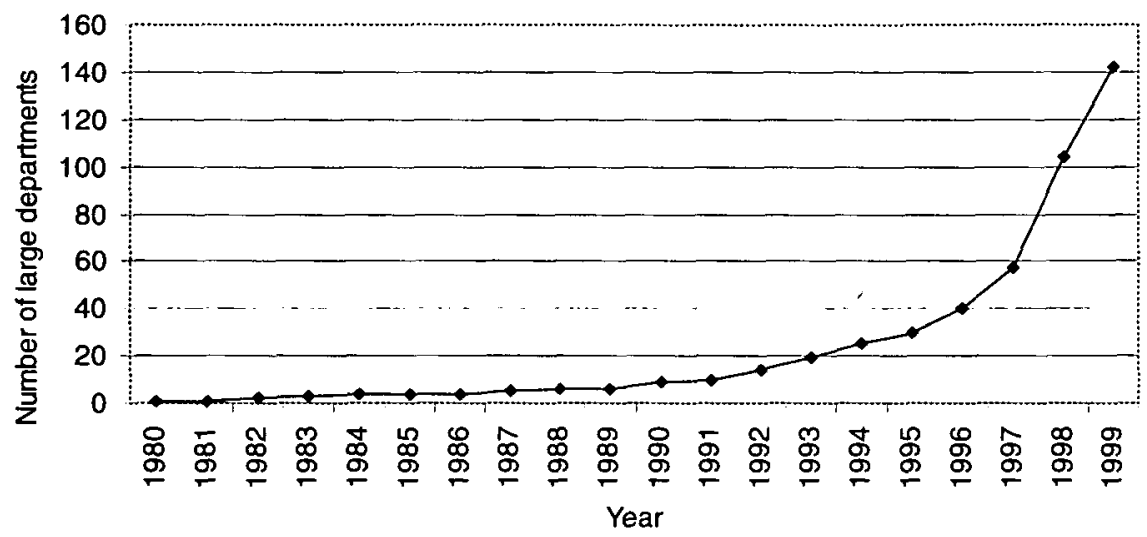

B. The Extrapolated Cumulative Adoption Curve for Compstat-like Programs

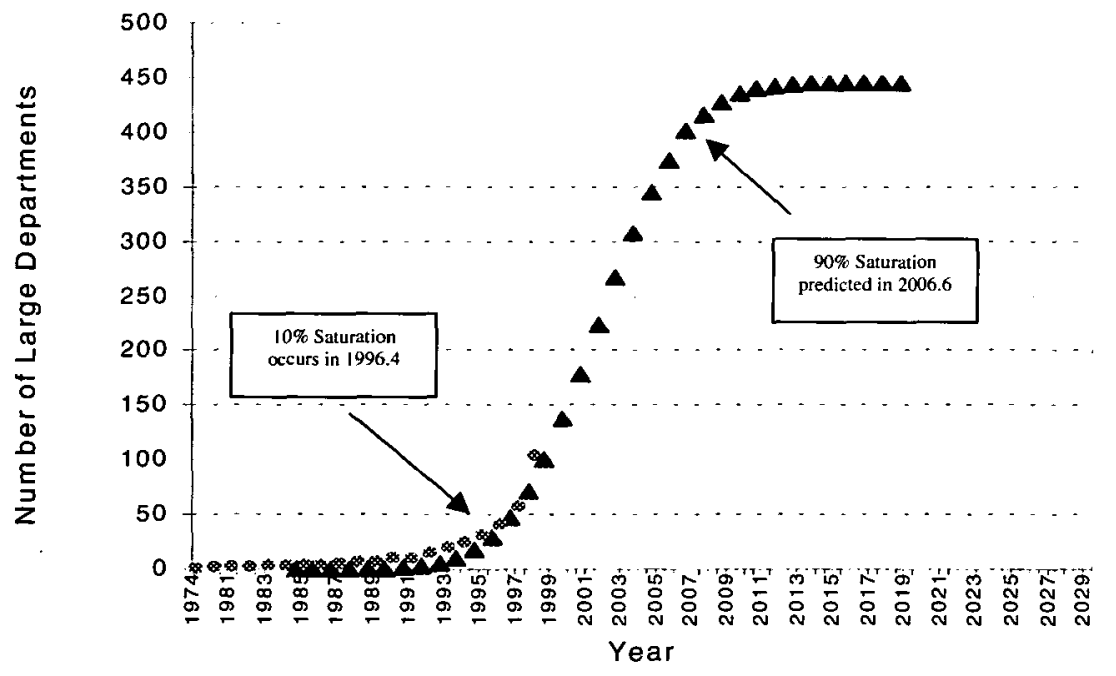

A Predicted numberó departments

* Observed number of departments 


\section{MOTIVATIONS BEHIND THE ADOPTION OF COMPSTAT}

What are the principal motivations for adopting Compstat, and how do these differ from those of agencies that do not intend to adopt Compstat? The survey affords an opportunity to observe patterns in priorities from which we might infer such motivations. Respondents were asked to rank the top five goals that the chief executive pursued in the previous 12 months, selecting from a list of 19.5 We assigned a score of 5 to the top priority goal identified by each respondent, a 4 to the second ranking goal, and so on, giving all unranked goals a score of 0 . Because we wanted to examine priorities of departments close to when they implemented a Compstat program, we excluded all departments that had implemented Compstat before 1998. We compare these departments with those that stated in the survey that they had not implemented a Compstat-like program and they were not planning to do so.

The average ranking for the 19 goals was 0.78 for the large department sample. Only four of the 19 items showed a statistically significant difference $(p<0.05)$ between the two groups of departments (Table 2$)$. Accordingly, there is a good deal of consensus in these police agencies regarding the priority goals for policing. However, departments that had recently implemented Compstat tended to rank the reduction of serious crime and increasing management control over field operations substantially higher than did departments that were not planning implementation of Compstat. Departments that were not planning to implement a Compstat-like program tended to score much higher than did departments that claimed to recently have adopted Compstat on the ranks they assigned to improving officer policing skills and employee morale.

Departments that had recently implemented Compstat gave the reduction of serious crime a priority ranking $1.5(3.32 / 2.26)$ times that of departments not planning to implement Compstat, and increasing management control a ranking of $2.1(.91 / .44)$ times that of such departments. Similarly, although in reverse, departments not planning to implement Compstat

5. The nineteen goals in the order listed were: reduce serious crime, reduce quality of life offenses, reduce fear of crime, reduce calls for service, increase citizen satisfaction with the police, increase service to citizens living in high-crime areas, increase efficiency of service (reduce cost per unit of service), reduce conflict among different segments of the community, increase citizen participation in police programs, increase citizens' ability to make their own neighborhoods better places to live, give citizen groups more influence over police policy and practice, improve coordination with other public and private organizations, reduce complaints about police misbehavior, increase police managers' control over actual field operations, improve officers' policing skills, improve employee morale, be more responsive to the priorities of individual neighborhoods, provide better service to crime victims, improve the physical appearance of neighborhoods. 


\section{TABLE 2. TOP FIVE GOALS PURSUED BY CHIEF EXECUTIVE IN LAST YEAR: STATISTICALLY SIGNIFICANT DIFFERENCES BY IMPLEMENTATION OF COMPSTAT}

\begin{tabular}{lcc}
\hline & \multicolumn{2}{c}{ Average Rank of Goal } \\
\cline { 3 - 3 } & $\begin{array}{c}\text { Compstat-like program } \\
\text { Implemented After } \\
1997(\mathrm{n}=79)\end{array}$ & $\begin{array}{c}\text { Not planning } \\
\text { Implementation } \\
(\mathrm{n}=178)\end{array}$ \\
\hline $\begin{array}{l}\text { Reduce serious crime*** } \\
\text { Increase police manager's control over field } \\
\text { operations* }\end{array}$ & 3.32 & 2.26 \\
$\begin{array}{l}\text { Improve officers' policing skills** } \\
\text { Improve employee morale** }\end{array}$ & 0.91 & 0.44 \\
\hline
\end{tabular}

${ }^{*} p<0.05 ;{ }^{* *} p<0.01 ; * * * p<0.001$.

NOTE: 19 goals were listed in the survey (see Note 5).

gave priority rankings to improving police officer skills that were on average $2.1(.96 / .46)$ times those of agencies that claimed to have recently implemented a Compstat like program, and priority rankings for improving employee morale that were on average $2.4(.68 / .28)$ times those of such agencies. This pattern is consistent with the interpretation that the dominant motivations for implementing Compstat are to secure management control over field operations that will reduce serious crime. At the same time, focus on improving skills and morale of street level officers, which for example have been high priorities in many community-policing programs, are relatively lower priorities for recently implemented Compstat departments.

\section{IMPLEMENTATION OF KEY ELEMENTS OF COMPSTAT IN COMPSTAT VERSUS NON- COMPSTAT DEPARTMENTS}

Clearly, many larger police agencies claim to have adopted a Compstat program. But do these agencies report having implemented the specific components we have defined as core elements of Compstat? Moreover, given our description of the emergence of strategic problem solving more generally in American policing, are there significant differences in claimed adoption of these elements of Compstat between departments that report having a Compstat or Compstat-like program and those that do not? Perhaps American police agencies have moved in the basic direction of strategic problem solving irrespective of the existence of Compstat. To analyze these issues, we identify specific practices that are associated with the six core elements of Compstat identified earlier. We asked a series of 
targeted questions meant to gauge the extent of a department's reported implementation of each of these components of the Compstat model.

\section{MISSION CLARIFICATION}

Two items measure the degree of mission clarification in Compstat departments, one about the specificity of the goal and the other about the simplicity versus multiplicity of the goal structure. Table 3 suggests that the degree of implementation of Compstat appears uneven, although a substantial proportion of these departments still meet these standards for mission clarification. Less than half of the departments that claim to have implemented a Compstat-like program had announced a goal of reducing crime or some other problem by a specific number, and almost a third of these departments have focused on "many different goals," reducing the clarity of the mission message. Nonetheless, we find statistically significant differences when we compare Compstat and non-Compstat departments. Compstat departments were more than twice as likely to set a public goal of reducing crime or other problems by a specific number. Although Compstat departments were significantly less likely to set many different goals, the absolute difference between Compstat and non-Compstat departments is only $11 \%$.

\section{TABLE 3. MISSION CLARIFICATION}

\begin{tabular}{lcc}
\hline & $\begin{array}{c}\text { Public goal of reducing crime or } \\
\text { other problem by specific number } \\
\text { or percent in the last } 12 \\
\text { months*** }(\mathrm{n}=428)\end{array}$ & $\begin{array}{c}\text { Department handles many } \\
\text { different goals selected by the } \\
\text { Chief* }(\mathrm{n}=428)\end{array}$ \\
\hline Compstat & $48.2 \%$ & $31.4 \%$ \\
Non-Compstat & $22.6 \%$ & $42.4 \%$ \\
\hline
\end{tabular}

${ }^{*} p<0.05 ;{ }^{* *} p<0.01 ; * * * p<0.001$.

\section{INTERNAL ACCOUNTABILITY}

Punishing middle managers who fail to meet the standards of Compstat accountability or rewarding those who do is a key element of internal accountability in the New York model (Bratton, 1998). Many Compstat departments take this element of Compstat seriously, and they are significantly more likely to report upholding accountability structures than are non-Compstat departments (Table 4A). Almost seven in ten agencies claiming to have implemented a Compstat-like program say that district commanders would be somewhat or very likely to be replaced if they do not know about the crime patterns in their district. This was true for less 
than half of the non-Compstat departments. In turn, Compstat departments were twice as likely as non-Compstat departments to report that a district commander would be replaced simply if crime continued to rise in a district. Although the use of "punishment" to maintain accountability is apparent in Compstat departments, we find that they are much less likely to use reward in ensuring internal accountability (Table 4B). If crime in a district declines, fewer than a quarter of Compstat departments report that it is very or somewhat likely that the district commander will be rewarded with a promotion or desired job assignment. Nonetheless, this is still about twice as many as report rewarding district commanders in nonCompstat departments.

\section{TABLE 4. INTERNAL ACCOUNTABILITY}

\section{A. PUNISHMENT AS A MEANS OF ENSURING INTERNAL ACCOUNTABILITY}

\begin{tabular}{lccc}
\hline & $\begin{array}{c}\text { If a district } \\
\text { commander does not } \\
\text { know about crime } \\
\text { patterns in the } \\
\text { district, the district } \\
\text { commander will be } \\
\text { replaced*** }(\mathrm{n}=422)\end{array}$ & $\begin{array}{c}\text { If crime in a district } \\
\text { stays at a high level } \\
\text { or continues to rise } \\
\text { over many months, } \\
\text { the district } \\
\text { commander will be } \\
\text { replaced }\end{array}$ & $\begin{array}{c}\text { If the commander of } \\
\text { a specialized unit } \\
\text { frequently fails to } \\
\text { fulfill requests for } \\
\text { cooperation from } \\
\text { district commanders, } \\
\text { the specialized unit } \\
\text { commander will be } \\
\text { replaced }(\mathrm{n}=422)\end{array}$ \\
\hline $\begin{array}{l}\text { Compstat } \\
\text { Non-Compstat }\end{array}$ & $67.6 \%$ & $42.4 \%$ & $78.4 \%$ \\
\hline
\end{tabular}

${ }^{*} p<0.05 ; * * p<0.01 ; * * * p<0.001$.

\section{B. REWARD AS A MEANS OF ENSURING INTERNAL ACCOUNTABILITY}

\begin{tabular}{lcc}
\hline & $\begin{array}{c}\text { If crime in a district declines over } \\
\text { many months, the district } \\
\text { commander will be promoted or } \\
\text { get a desired job assignment** } \\
(\mathrm{n}=420)\end{array}$ & $\begin{array}{c}\text { unit routinely fulfills requests for } \\
\text { assistance from district } \\
\text { commanders, the specialized unit } \\
\text { commander will be promoted or } \\
\text { get a desired job assignment } \\
(\mathrm{n}=421)\end{array}$ \\
$\begin{array}{l}\text { \% Very or } \\
\text { Somewhat Likely }\end{array}$ & $23.2 \%$ & $37.4 \%$ \\
\hline Compstat & $12.8 \%$ & $37.6 \%$ \\
Non-Compstat & & \\
\hline
\end{tabular}

${ }^{*} p<0.05 ; * * p<0.01 ; * * * p<0.001$.

The one area of internal accountability where there are not statistically significant differences between Compstat and non-Compstat departments is that related to special units. Both Compstat and non-Compstat departments claim that special unit commanders are likely to be replaced if they frequently fail to "fulfill requests for cooperation from district commanders." In turn, about $37 \%$ of both Compstat and non-Compstat 
departments report special unit commanders are likely to be rewarded if they routinely fulfill requests for assistance from district commanders.

\section{GEOGRAPHIC ORGANIZATION OF OPERATIONAL COMMAND}

When we ask whether departments give authority to middle managers to select problem-solving strategies for low-level problems we find strong support for the Compstat emphasis on geographic organization of command (Table 5). Ninety percent of departments claiming to have implemented a Compstat-like program report giving district commanders, line supervisors, or specialized unit commanders such authority. However, this was also true for $86 \%$ of non-Compstat departments. In the case of high visibility problems, there is somewhat less support for allowing commanders at that level the authority to choose problem-solving strategies, and in this case, there is a significant difference between Compstat and non-Compstat departments. This was the case for $70 \%$ of Compstat departments and $54 \%$ of non-Compstat departments.

\section{TABLE 5. GEOGRAPHIC ORGANIZATION OF OPERATIONAL COMMAND}

\begin{tabular}{lcc}
\hline Decision & $\begin{array}{c}\% \text { Yes } \\
\text { Compstat }\end{array}$ & $\begin{array}{c}\% \text { Yes } \\
\text { Non-Compstat }\end{array}$ \\
\hline $\begin{array}{l}\text { District Commander, Line Supervisor, or Specialized Unit } \\
\text { Commander selects problem solving strategies for low- }\end{array}$ & $90.1 \%$ & $86.1 \%$ \\
$\begin{array}{l}\text { profile problems ( }=430) \\
\text { District Commander, Line Supervisor, or Specialized Unit } \\
\quad \text { Commander selects problem solving strategies for high- } \\
\text { profile problems** (n = 433) }\end{array}$ & $69.7 \%$ & $54.3 \%$ \\
$\begin{array}{l}\text { District Commander, Line Supervisor, or Specialized Unit } \\
\quad \text { Commander determines routine staffing levels for patrol } \\
\text { shifts (n=433) }\end{array}$ & $38.7 \%$ & $31.3 \%$ \\
$\begin{array}{l}\text { District Commander, Line Supervisor, or Specialized Unit } \\
\text { Commander determines beat boundaries (n=429) }\end{array}$ & $19.0 \%$ & $13.9 \%$ \\
\hline
\end{tabular}

${ }^{*} p<0.05 ;{ }^{* *} p<0.01 ; * * * 00.001$.

When we examine the extent to which departments are willing to give middle managers greater responsibility for determining beat boundaries or staffing levels, we find less support for the idea of geographic organization of command. Only four in ten departments that claim to have implemented a Compstat-like model give district commanders, line supervisors, or specialized unit commanders the authority to determine routine staffing levels for patrol shifts, and this is not significantly different from the proportion of non-Compstat departments. Moreover, only $19 \%$ of Compstat 
departments and $14 \%$ of non-Compstat departments claim to give such commanders the authority to determine beat boundaries.

\section{ORGANIZATIONAL FLEXIBILITY}

We examined organizational flexibility in two ways. First, we asked departments whether middle managers had general authority to approve requests for flexible hours or to mobilize SWAT units to support specific operations (Table 6A). Although these two items also reflect the commitment of the department to geographic organization of command, they do focus directly on whether there is flexibility in the allocation of departmental resources. Three-quarters of Compstat departments responded that they allow district commanders, line supervisors, or specialized unit commanders to decide on flexible hour requests, and $65 \%$ allow them to mobilize SWAT units. Importantly, however, the difference in the proportions of Compstat and non-Compstat departments that evidenced these indicators of organizational flexibility is small and not statistically significant.

We also examined how much organizational flexibility departments reported in dealing with "the crime/disorder problem that used more of the department's effort than any other problem in the last 12 months" (Table 6B). Again, departments that claim to have implemented a Compstat-like program do appear to allow a good deal of organizational flexibility. Eighty-four percent of these departments had reassigned patrol officers to new units, areas, or work shifts to address this problem. And on this measure, Compstat departments were significantly different from nonCompstat departments in which only $69 \%$ claimed such reassignments. Eighty percent of the departments had used overtime to provide personnel to deal with the problem, although this proportion is close to that in nonCompstat departments. Although few of the departments allowed reassignment of civilian employees, reflecting perhaps contract or other restrictions, about six in ten Compstat departments had reassigned criminal investigators (as compared with $51 \%$ of non-Compstat departments) and $66 \%$ other sworn specialists (as compared to $53 \%$ in non-Compstat departments) to new units, areas, or work shifts.

\section{DATA-DRIVEN PROBLEM IDENTIFICATION AND ASSESSMENT}

Compstat departments claim to have the capability to manage and analyze crime data in sophisticated ways, and they are significantly more likely to claim this than non-Compstat departments (Table 7A). Over $90 \%$ of these departments claim to conduct "crime trend identification and analysis" (as contrasted with $72 \%$ of non-Compstat departments), and 


\section{TABLE 6. ORGANIZATIONAL FLEXIBILITY}

\section{A. ORGANIZATIONAL FLEXIBILITY (GENERAL ITEMS)}

\begin{tabular}{|c|c|c|}
\hline Decision & $\begin{array}{c}\% \text { Yes } \\
\text { Compstat }\end{array}$ & $\begin{array}{c}\% \text { Yes } \\
\text { Non-Compstat }\end{array}$ \\
\hline $\begin{array}{l}\text { District Commander, Line Supervisor, or Specialized Unit } \\
\text { Commander approves flexible hour requests for sworn } \\
\text { personnel }(\mathrm{n}=428)\end{array}$ & $75.0 \%$ & $67.4 \%$ \\
\hline $\begin{array}{l}\text { District Commander, Line Supervisor, or Specialized Unit } \\
\text { Commander mobilizes SWAT unit to support operations } \\
(n=424)\end{array}$ & $65.2 \%$ & $62.9 \%$ \\
\hline
\end{tabular}

${ }^{*} p<0.05 ;{ }^{* *} p<0.01 ;{ }^{* *} p<0.001$.

B. ORGANIZATIONAL FLEXIBILITY IN DEALING WITH A HIGH-PRIORITY PROBLEM

\begin{tabular}{|c|c|c|}
\hline Change made to deal with specified problem & $\begin{array}{c}\% \text { Yes } \\
\text { Compstat }\end{array}$ & $\begin{array}{c}\% \text { Yes } \\
\text { Non-Compstat }\end{array}$ \\
\hline $\begin{array}{l}\text { Reassign patrol officers to new units, areas, or work shifts*** } \\
(n=422)\end{array}$ & $84.3 \%$ & $68.8 \%$ \\
\hline Use overtime to provide personnel $(n=424)$ & $80.0 \%$ & $74.3 \%$ \\
\hline $\begin{array}{l}\text { Reassign civilian employees to new units, areas, or work shifts } \\
(n=420)\end{array}$ & $28.6 \%$ & $21.1 \%$ \\
\hline $\begin{array}{l}\text { Reassign criminal investigators to new units, areas, or work } \\
\text { shifts }(n=423)\end{array}$ & $59.3 \%$ & $50.5 \%$ \\
\hline $\begin{array}{l}\text { Reassign other sworn specialists to new units, areas, or work } \\
\text { shifts* }(n=420)\end{array}$ & $65.5 \%$ & $52.7 \%$ \\
\hline
\end{tabular}

${ }^{*} p<0.05 ;{ }^{* *} p<0.01 ; * * * p<0.001$.

almost $90 \%$ claim to use "database or statistical analysis software for crime analysis" (as contrasted with $76 \%$ of non-Compstat departments). In turn, we find meaningful differences between Compstat and non-Compstat departments in the claimed availability of analysis tools. The largest differences are found in regard to crime mapping, reflecting the centrality of crime mapping to Compstat programs. But even here many departments that have not implemented a Compstat-like program are using crime mapping. For example, there is a $32 \%$ gap between Compstat and non-Compstat departments in use of mapping software. Nonetheless, more than half of the non-Compstat departments report that they are using mapping software for crime analysis.

Departments that claim to have implemented a Compstat-like program are clearly sophisticated in their ability to use data, but are those data available in a timely fashion? Again, Compstat departments appear very much to follow the emphasis placed on timely data in the Compstat model (Table 7B). But here we find little difference between those departments that claim to have implemented a Compstat-like model and others. About three-quarters of all the departments report that calls for service information are immediately available or available the same day. Arrest data are 


\section{TABLE 7. DATA-DRIVEN PROBLEM IDENTIFICATION AND ASSESSMENT}

A. THE AVAILABILITY OF CRIME MAPPING AND OTHER CRIME ANALYSIS TOOLS

\begin{tabular}{|c|c|c|c|c|c|}
\hline \multicolumn{4}{|c|}{ Crime mapping and other crime analysis tools are available } & $\begin{array}{l}\% \text { Yes } \\
\text { Compstat }\end{array}$ & $\begin{array}{c}\% \text { Yes } \\
\text { Non-Compstat }\end{array}$ \\
\hline \multirow{2}{*}{\multicolumn{4}{|c|}{$\begin{array}{l}\text { Crime trend identification and analysis*** }(n=419) \\
\text { Database or statistical analysis software for crime analysis** } \\
(n=433)\end{array}$}} & $93.4 \%$ & $71.7 \%$ \\
\hline & & & & $88.7 \%$ & $75.9 \%$ \\
\hline \multicolumn{4}{|c|}{ Mapping software for crime analysis*** $(n=433)$} & $85.2 \%$ & $52.9 \%$ \\
\hline \multicolumn{4}{|c|}{ Pin mapping-of specific crimes by type ${ }^{* * *}(n=426)$} & $91.4 \%$ & $75.5 \%$ \\
\hline \multicolumn{4}{|c|}{$\begin{array}{l}\text { Pin mapping-of crimes by specific suspect or m.o.*** } \\
(n=413)\end{array}$} & $65.7 \%$ & $39.9 \%$ \\
\hline & $87.9 \%$ & $65.3 \%$ \\
\hline \multicolumn{4}{|c|}{$\begin{array}{l}\text { Pin mapping- of crime activity for all crimes by area*** } \\
(n=424)\end{array}$} & $77.1 \%$ & $55.3 \%$ \\
\hline \multicolumn{6}{|c|}{${ }^{*} p<0.05 ;^{* *} p<0.01 ;^{* * *} p<0.001$} \\
\hline \multicolumn{6}{|l|}{ B. TIMELY DATA } \\
\hline $\begin{array}{l}\text { \% Data Available } \\
\text { Immediately or } \\
\text { Same Day }\end{array}$ & $\begin{array}{l}\text { Calls for Service } \\
\quad(n=434)\end{array}$ & $\begin{array}{c}\text { Arrest } \\
(\mathrm{n}=434)\end{array}$ & $\begin{array}{c}\text { Crime } \\
\text { Incident } \\
(\mathrm{n}=432)\end{array}$ & $\begin{array}{l}\text { Citation } \\
(\mathrm{n}=433)\end{array}$ & $\begin{array}{c}\text { Field } \\
\text { Interrogation } \\
(n=432)\end{array}$ \\
\hline $\begin{array}{l}\text { Compstat } \\
\text { Non-Compstat }\end{array}$ & $\begin{array}{l}76.8 \% \\
74.3 \%\end{array}$ & $\begin{array}{l}56.3 \% \\
55.1 \%\end{array}$ & $\begin{array}{l}48.2 \% \\
44.0 \%\end{array}$ & $\begin{array}{l}33.8 \% \\
36.4 \%\end{array}$ & $\begin{array}{l}31.9 \% \\
29.6 \%\end{array}$ \\
\hline
\end{tabular}

${ }^{*} p<0.05 ;{ }^{* *} p<0.01 ;{ }^{* * *} p<0.001$.

also very timely, with more than half the departments reporting that such data are available immediately or on the same day.

\section{INNOVATIVE PROBLEM-SOLVING TACTICS}

We considered two ways in which problem solving might be innovative: how problems are analyzed and selected and whether the solutions selected were a break from traditional law-enforcement methods. Police have long collected data and compiled statistics, but those data were rarely used to make important decisions about how to solve problems (Mastrofski and Wadman, 1991). Compstat is intended to harness problem-solving decisions to data analysis. When asked specifically whether statistical analysis software is used for problem solving, about $70 \%$ of the Compstat departments answer yes (Table 8A). Sixty-seven percent say that crimemapping software is used for problem-solving efforts. In this case, Compstat departments are significantly more likely to claim to use such technologies for problem solving than are non-Compstat departments. Nonetheless, a majority of non-Compstat departments claim to use data 
base or statistical analysis software for problem solving, and more than a third claim to use mapping software for problem solving.

\section{TABLE 8. INNOVATIVE PROBLEM SOLVING TACTICS}

A. THE TECHNOLOGY USED FOR PROBLEM SOLVING

\begin{tabular}{lcc}
\hline Technology used for problem solving & $\begin{array}{c}\% \text { Yes } \\
\text { Compstat }\end{array}$ & $\begin{array}{c}\% \text { Yes } \\
\text { Non-Compstat }\end{array}$ \\
\hline Database or statistical analysis software for problem solving** & & \\
$(\mathrm{n}=433)$ & $69.0 \%$ & $54.3 \%$ \\
Mapping software for problem solving*** $(\mathrm{n}=433)$ & $66.9 \%$ & $38.5 \%$ \\
\hline
\end{tabular}

${ }^{*} p<0.05 ; * * p<0.01 ; * * * p<0.001$.

\section{B. DECIDING UPON PROBLEM-SOLVING STRATEGIES}

\begin{tabular}{|c|c|c|}
\hline $\begin{array}{l}\text { Importance of the following in deciding which } \\
\text { tactics or methods to use to solve a high-priority } \\
\text { problem }\end{array}$ & $\begin{array}{l}\text { \% Very Important } \\
\text { Compstat }\end{array}$ & $\begin{array}{l}\% \text { Very Important } \\
\text { Non-Compstat }\end{array}$ \\
\hline \multirow{4}{*}{$\begin{array}{l}\text { Previous success with the approach }(n=421) \\
\text { Research evidence suggesting this was the best } \\
\text { approach* }(n=418) \\
\text { Other departments' reported previous success } \\
\text { with the approach }(n=416) \\
\text { Outside experts recommending this approach } \\
(n=418)\end{array}$} & $66.2 \%$ & $68.1 \%$ \\
\hline & $39.6 \%$ & $28.7 \%$ \\
\hline & $32.4 \%$ & $28.9 \%$ \\
\hline & $15.1 \%$ & $11.5 \%$ \\
\hline \multicolumn{3}{|l|}{$* p<0.05 ; * * p<0.01 ; * * * p<0.001$} \\
\hline \multicolumn{3}{|c|}{$\begin{array}{l}\text { C. TACTICS USED TO SOLVE PRIORITY CRIME/DISORDER PROBLEM IN LAST } \\
12 \text { MONTHS: STATISTICALLY SIGNIFICANT COMPARISONS }\end{array}$} \\
\hline Strategy & $\begin{array}{l}\% \text { Used Tac } \\
\text { Compstat }\end{array}$ & $\begin{array}{ll}\text { etic } & \% \text { Used Tactic } \\
\mathrm{t} & \text { Non-Compstat } \\
\end{array}$ \\
\hline Increasing Arrests for Targeted Offenders** $(\mathrm{n}=$ & $73.8 \%$ & $59.8 \%$ \\
\hline Check Points* $(n=427)$ & $31.2 \%$ & $20.6 \%$ \\
\hline Targeting Repeat Offenders** $(n=427)$ & $56.0 \%$ & $42.0 \%$ \\
\hline Gun Seizures** $(n=427)$ & $27.0 \%$ & $15.0 \%$ \\
\hline Improving Victim Services* $(n=427)$ & $22.7 \%$ & $14.0 \%$ \\
\hline
\end{tabular}

Improving Victim Services* $(n=427)$

${ }^{*} p<0.05 ; * * p<0.01 ; * * * p<0.001$.

NOTE: The full list of tactics also included saturation of an area with police, educating the public, mobilizing community groups, mobilizing other public/private agency, intensive enforcement of minor offenses, nuisance abatement law enforcement, buy-bust operations, mobilizing other law enforcement, increasing traffic enforcement, warrant checks on arrestees, altering the phystical environment, sting operations, enforcing laws not enforced earlier, pressuring other agencies to improve service, seeking new laws, improving victim services, improving response time, mediating between conflicting parties, and vertical patrols in buildings.

Both Compstat and non-Compstat departments use crime mapping and other innovative data analysis approaches for problem solving, but this 
does not necessarily mean that such efforts have significant depth. One element often mentioned by those advocating innovation in problem solving is that departments look beyond their own experiences in identifying innovative strategies to solve problems. This does not seem to be the case very often in Compstat or non-Compstat departments. When we asked departments how they decided on a problem-solving strategy to address "the one crime/disorder problem that used more of the department's efforts than any other problem in the last 12 months," they were most likely to tell us that they relied on the department's previous success with that approach (Table $8 \mathrm{~B}$ ). Very few of the departments stated that they draw significantly from outside experts. Nonetheless, reflecting the growing openness of police agencies to research, they were more likely to tell us that "research evidence" was very important in deciding a strategy. About four in ten Compstat departments and three in ten non-Compstat departments reported this, and this difference was statistically significant. About a third of the departments overall reported that they had drawn from experiences of other departments.

When we look at specific tactics used to address the priority crime/disorder problem identified by sample departments in the last 12 months, we also find a good deal of similarity between Compstat and non-Compstat departments. The most common strategies used by both Compstat and non-Compstat departments relied on traditional police-enforcement strategies. For example, the first ranked strategy for both types of departments was "saturation of an area with police," noted by $79 \%$ of Compstat Departments and $76 \%$ of non-Compstat departments. Many of the departments said that they had used such innovative tactics as nuisance abatement or altering the physical environment. Tactics that sought to involve the community in crime control efforts also ranked high, for example, in "educating the public" and "mobilizing community groups." In only 5 of the 23 tactics examined were differences between Compstat and nonCompstat departments found to be statistically significant (Table 8C). Compstat departments were significantly more likely to increase arrests for targeted offenders, and target repeat offenders, use checkpoints, increase gun seizures, or improve victim services.

\section{DISCUSSION: COMPSTAT AND TRADITIONAL POLICE ORGANIZATIONAL CULTURE}

One of the clearest findings of our study is that Compstat has spread widely and quickly across larger American police agencies. In our survey, conducted just five years after the New York City police department had coined the term Compstat, a third of departments with 100 or more sworn officers reported that they had implemented a "Compstat-like program," 
and an additional quarter of these departments claimed to be planning such a program. This speed of diffusion of innovation places Compstat among those social and technological innovations that are adopted most quickly. We suspect, although we do not have comparative data on American police innovations, that this speed of adoption is also unusual for innovations in American policing. Compstat as a cohesive program debuted only in 1994. Moreover, unlike community policing, the federal government has not provided direct financial incentives for its implementation (Roth et al., 2000). ${ }^{6}$ It is fair to say that Compstat as a recognized programmatic model has literally burst on to the American police scene.

Why has Compstat diffused so quickly and widely? One reason is the promise of Compstat in controlling crime. Although it is generally recognized that technical success of programs is not a sufficient explanation for their adoption in police agencies (Crank and Langworthy, 1992; Manning, 1997; Mastrofski, 1998), police departments that have implemented a Compstat-like program often point to the promise of Compstat as a crimeprevention tool. In turn, although there is significant debate in academic circles regarding the effectiveness of Compstat (e.g., see Eck and Maguire, 2000; Kelling and Sousa, 2001), there has been much less reticence among those who created the program and the media in touting its success. The program was widely discussed in the popular and professional news outlets, even leading to William Bratton being featured on the cover of Time Magazine in January 1996. In turn, the agency that created this program was the most visible local police agency in the nation and did a great deal to publicize it and show other agencies how it operates. As other big cities began to adopt their own Compstat programs, this too increased the "buzz" in the press and among police agencies, helping to make it the "hot" program for local law enforcement leaders.

Our study illustrates a second reason why Compstat has spread so quickly: A number of American police agencies had already adopted many of its features before the term Compstat was coined and marketed. At the outset of our paper, we described a wider movement toward strategic problem solving in American policing. Our survey shows that many elements of strategic problem solving had begun to be implemented more widely across American police agencies before the emergence of Compstat, and have been adopted broadly even by departments that have not formally adopted a Compstat program. Some even claimed to have been engaged in all of the elements of Compstat before 1994. So, the New York City Police Department's contribution appears to be its leadership in

6. However, federal "community policing" grants have supported some key elements of Compstat, such as the promotion of problem solving and the acquisition of computers and other information technology to support crime analysis. 
bringing all of these elements together into a single program, giving it a clear, coherent role, and providing a highly publicized set of claims that link it to performance-the decline of crime and disorder in the nation's most visible city.

However, our study suggests that Compstat's origins in a highly visible police agency, the attractiveness of its crime control promises, and the fact that many of its components were already being implemented in other departments before its emergence as a formal programmatic entity provide only part of the story behind the rapid adoption of Compstat-like programs in larger American police agencies. Compstat is appealing precisely because it holds out the promise of innovation in police organization, strategies, and tactics but does not demand a revolution in the organizational structure of American policing. Rather, it preservesindeed, claims to reinvigorate-the traditional hierarchical structure of the military model of policing, a structure that has been attacked by a powerful reform wave over the last two decades.

Many scholars have used the terms "bureaucratic" or "para-military" to describe the form of traditional police organization (e.g., see Bittner, 1980; Davis, 1981; Goldstein, 1977; Melnicoe and Menig, 1978; Punch, 1983; Weisburd et al., 1988). Police departments have traditionally relied on a highly articulated set of rules defining what officers should and should not do in various situations to ensure internal control. This supervisory system is strongly hierarchical and essentially negative, relying primarily on sanctions for noncompliance with police rules and regulations. Importantly, this bureaucratic, military model of organization increasingly came under attack as scholars sought to understand and respond to a growing body of research that suggested the police were ineffective in controlling crime and responding to community problems (Bayley, 1994; Goldstein, 1990; Greene and Mastrofski, 1988; Mastrofski, 1998; Skolnick and Bayley, 1986). As Weisburd et al. (1988:31-32) note:

Whatever the historical achievements of the bureaucratic, military model of organization, its shortcomings are increasingly evident to scholars and police administrators who argue that the demands of contemporary urban society undermine the assumptions upon which traditional police structures were built. While the military model depends on predictability, many of the situations to which officers are asked to respond cannot be anticipated. Though the norms that define appropriate responses may reduce the vulnerability of officers to criticism, they often do not provide useful guides for developing effective solutions to the problems encountered. Finally deployment patterns which treat patrol officers as if they were interchangeable parts (as well as highly centralized structures of authority and decision-making) prevent police officers from learning and responding to 
distinctive problems, needs and resources of the neighborhoods they serve.

The challenge to the military model of American police organization was most clearly articulated by advocates of community policing. Community policing emerged on the scene in the 1980s and quickly became the most important police reform of the decade (Bayley, 1988; Greene and Mastrofski, 1988). At a time when many scholars had literally given up on the possibility that the police could increase the safety of American communities (Bayley, 1994; Gottfredson and Hirschi, 1990), community policing offered the promise of an American policing that would not only allow Americans to feel safer but that would actually make them safer. Although community policing is most commonly associated with a movement toward greater police recognition of the role of the community in the police mission, it included a strong current of dissatisfaction with traditional bureaucratic, top-down command-and-control management (Mastrofski, 1998; Weisburd et al., 1988). Community policing, at least as articulated by some of its most visible advocates (Brown, 1989; Goldstein, 1990; Skolnick and Bayley, 1986; Trojanowicz and Bucqueroux, 1990), promotes the true professionalization of the rank-and-file, who, equipped with the necessary training, education, and motivation to solve problems, are supposed to use their best judgment to make important decisions about how to serve the neighborhoods to which they are assigned. Some scholars have called this a movement toward "decentralization of command" or "debureaucratization" (Matrofski, 1998; Skolnick and Bayley, 1987). In turn, resistance of police organizations to the challenge of decentralization has been noted as an important impediment to the implementation of community policing (Weisburd et al., 2002).

Compstat presents an alternative model for police organization that also holds promise for improving American policing. It replaces the bubble-up professionalism proposed by many community policing advocates with a revitalized cadre of middle managers (especially district commanders), who are given general objectives by top management and given the authority and resources to get things done. But they are at the same time held accountable for at least making the effort to achieve management's goals and are required to be well informed about the consequences, even if the desired results are not always forthcoming. Compstat seeks to empower police organization by harnessing the hierarchy to achieve top management's objectives.

But if Compstat preserves, or perhaps enhances, the relevance of the hierarchy for controlling the organization, it still deserves to be called innovative, at least in principle. Rather than the sort of constant surveillance thought effective in running organizations that require standardization (e.g., assembly lines), a model once blessed by police reformers, but 
realized only chimerically, the Compstat model requires striking a delicate balance between empowerment and control (Simons, 1995). The question is, what sort of balance have America's Compstat police agencies actually struck? Our survey data, although certainly not the last word on this issue, suggest that most Compstat agencies have in fact opted for a model much heavier on control than on empowerment.

When we compared department goals of recent innovators with those who were not intending to develop a Compstat program, we found that the most significant differences were in the areas of crime control, increased control of managers over field operations, improving rank- andfile policing skills, and improving police morale. Importantly, departments that had claimed to have recently adopted Compstat were more concerned with reducing crime and increasing internal accountability than were departments that reported neither to have nor to be planning to develop a Compstat-like program. In contrast, they ranked much lower on items that emphasized rank-and-file professionalism and esprit. These findings are certainly consistent with a view that sees Compstat programs as reinforcing the traditional control elements of the military model of police organization.

In turn, although fairly strong on mission clarification, internal accountability, and use of data, in our survey, Compstat agencies were largely indistinguishable from non-Compstat agencies on measures that gauged geographic organization of command, organizational flexibility, the timely availability of data, and the selection and implementation of innovative strategies and tactics. More generally, our data present a picture of departments that have embraced control of middle managers (tending to rely more heavily on punitive than on positive consequences) and adopting advances in information technology. At the same time, we find that Compstat departments are more reluctant to relinquish power that would decentralize some key elements of decision making geographically (letting precinct commanders determine beat boundaries and staffing levels), enhance flexibility, and risk going outside of the standard tool kit of police tactics and strategies. The combined effect overall, whether or not intended, is to reinforce a traditional bureaucratic model of command and control.

But does Compstat empower police organization more generally through its emphasis on the accountability of police managers? In theory, the original developers of Compstat did not dispute the community policing view that giving "cops more individual power to make decisions is a good idea" (Bratton, 1998:198). However, they believed that in the real world of police organization, street-level police officers "were never going to be empowered to follow through" (Bratton, 1998:199). Compstat was seen as offering a solution to this problem. It did not necessarily lead to a 
de-emphasis on the training and esprit of street-level police officers, but it did place the burden on empowering police organization in the hands of middle managers.

Our survey of police agencies cannot demonstrate it, but our observations in Compstat departments suggest that the rank-and-file remain largely oblivious to Compstat and that it intrudes little, if at all, into their daily work (Willis et al., 2003). As one patrol officer put it when asked about Compstat, "if you don't go [to Compstat meetings], you don't know." In that department, in contrast to almost the entire command staff, only two or three patrol officers are present at any given Compstat meeting. They may answer a question or two, and they may give a brief presentation, but they play a peripheral role. A high-ranking officer we interviewed remarked that "patrol officers can hide in the meeting and get away without saying anything." Whereas members of the command staff in Compstat departments we observed, in particular, the sector captains, are expected to respond to the Chief's questions, line officers are rarely called on to explain a particular decision. It is true that a sector captain who has been "roasted" in Compstat for an inadequate strategy may return to his sector and rebuke his line officers, but the force of the message is considerably weakened for three reasons: (1) Compstat ultimately holds middle managers, not line officers, accountable; (2) the message is not being delivered by the highest ranking official in the police department; and (3) it does not result in public censure on the same scale.

Our field observations suggest that in Compstat agencies the problemsolving processes are principally the work of precinct commanders, their administrative assistant, and crime analysis staff (sometimes available at the precinct level, as well as at headquarters). The pressures on these people can be quite profound. One precinct commander noted, "We're under constant pressure. It's the toughest job in this department. We're held a little closer to the fire... .I'll go home at night after ten hours at work and keep working - 50-60 hours per week on average." His lieutenant reinforced this. "A precinct commander has no life [outside Compstat]." Although this level of intense accountability was commonly expressed by middle managers in Compstat departments, we found nothing remotely resembling that at lower levels in the organization, except on the rare occasion when a rank-and-file officer was required to make a substantial presentation at a department Compstat meeting. A few agencies we visited did routinely conduct precinct-level Compstat meetings, and here there appeared to be greater involvement by a large number of first-line supervisors and some of their subordinates. Kelling and Sousa (2001) argue that this is what is happening in New York City, where they observed numerous instances of creative precinct-level problem solving. 
Just how widespread such a practice becomes among the precincts of Compstat departments around the nation remains to be seen.

\section{CONCLUSIONS}

In introducing our paper, we presented two very different views of the role of innovation in preserving organizations. The first is that of the great Whig orator, Lord Macaulay, who recognized that change was sometimes necessary to preserve institutions. He told his colleagues in Parliament: "Reform, that you may preserve." The second is drawn from di Lampedusa's novel The Leopard describing the conflicts that surrounded the reunification of the Italian peninsula in the nineteenth century. Here reform is seen as more illusory: "If we want everything to remain the same, then everything is going to have to change."

Our paper documents a process of "diffusion of innovation" (see Rogers, 1995) of Compstat-like programs in larger police agencies that follows a surprisingly rapid pace. At the same time, our data suggest that many elements of strategic problem solving had begun to be implemented more widely across American police agencies before the emergence of Compstat as a programmatic entity, and they had been adopted broadly even by departments that had not formally adopted a Compstat program. In many ways, the rapid ascendance of Compstat can be seen as evidence of Lord Macaulay's prescription. In order to reinvigorate and preserve police organization, police managers have adopted a model of strategic problemsolving (Compstat) that in theory allows police agencies to utilize innovative technologies and problem-solving techniques while empowering traditional police organizational structures. However, our analysis suggests that at this stage, what most characterizes Compstat departments and distinguishes them from others is the development of the control element of reform. This of course raises the question of whether American police agencies have adopted Compstat enthusiastically more because of its promise of reinforcing the traditional hierarchical model of police organization than for its efforts to empower problem solving in police agencies. In this context, we may wonder whether in practice, although not necessarily with intent, police agencies have followed an approach that is more consistent with that described by di Lampedusa than by Lord Macaulay.

\section{REFERENCES}

Anselin, Luc, Jacqueline Cohen, David Cook, Wilpen Gorr, and George Tita 2000 Spatial analyses of crime. In David Duffee, David McDowall, Brian Ostrom, Robert D. Crutchfield, Stephen D. Mastrofski, and Lorraine Green Mazerolle (eds.), Measurement and Analysis of Crime and Justice. Washington, D.C.: National Institute of Justice. 
Bayley, David

1988 Community policing: A report from the Devil's advocate. In Jack $R$. Greene and Stephen D. Mastrofski (eds.), Community Policing: Rhetoric or Reality. New York: Praeger.

1994 Police for the Future. New York: Oxford University Press.

Beer, Michael

1980 Organization Change and Development: A Systems View. Santa Monica, Calif:: Goodyear Publishing Company.

Berman, Jesse

1987 Police Administration and Progressive Reform. New York: Greenwood.

Bittner, Egon

1980 The Functions of the Police in Modern Society. Cambridge, Mass.:

Oelgeschlager, Gunn and Hain.

Bouza, Tony

1997 NYPD Blues-Good, Lucky, or Both? Law Enforcement News (January $31): 8,10$.

Braga, Anthony

2001 The effects of hot spots policing on crime. Annals of the American Academy of Political and Social Sciences 578:104-125.

Bratton, William

1996 Cutting Crime and Restoring Order: What America Can Learn from New York's Finest. Heritage Foundation Lectures and Educational Programs, Heritage Lecture \#573. Available at www.nationalsecurity.org/heritage/ library/categories/crimelaw/lect573.html.

1998 Turnaround: How America's Top Cop Reversed the Crime Epidemic. New York: Random House.

1999 Great expectations: How higher expectations for police departments can lead to a decrease in crime. In Robert $\mathrm{H}$. Langworthy (ed.), Measuring What Matters: Proceedings from the Policing Research Institute Meetings. Washington, D.C.: National Institute of Justice.

Brown, Lee $\mathbf{P}$.

1989 Community Policing: A Practical Guide for Police Officials. Washington, D.C.: National Institute of Justice.

Bureau of Justice Statistics

1998 Census of State and Local Law Enforcement Agencies, 1996. Washington, D.C.: U.S. Department of Justice, Bureau of Justice Statistics.

Crank, John P. and Robert Langworthy

1992 An institutional perspective of policing. Journal of Criminal Law and Criminology 83:338-63.

Davis, E.M.

1981 Professional Police Principles. In H.W. More, Jr. (ed.), Critical Issues in Policing. Cincinatti, Ohio: Anderson Publishing Company.

Eck, John E. and Edward R. Maguire

2000 Have changes in policing reduced violent crime? An assessment of the evidence. In Alfred Blumstein and Joel Wallman, (eds.), The Crime Drop in America. Cambridge, U.K.: Cambridge University Press. 
Finkelstein, Sydney and Donald C. Hambrick

1996 Strategic Leadership: Top Executives and Their Effects on Organizations. St. Paul, Minn.: West Publishing Co.

Fogelson, Robert F.

1977 Big City Police. Cambridge, Mass.: Harvard University Press.

Giuliani, Rudolph W. and Howard Safir

1998 Compstat: Leadership in Action. New York City: New York City Police Department.

Goldstein, Herman

1977 Policing a Free Society. Cambridge, Mass.: Ballinger Publishing Company

1990 Problem-Oriented Policing. New York: McGraw-Hill.

Gottfredson Michael R. and Travis Hirschi

1990 General Theory of Crime. Stanford, Calif.: Stanford University Press.

Greene, Jack R. and Stephen D. Mastrofski

1988 Community Policing: Rhetoric or Reality. New York: Praeger.

Greeńspan, Rosann, Stephen D. Mastrofski, and David Weisburd

2003 Compstat and Organizational Change: Short Site Visits Report. Washington, D.C.: Police Foundation.

Grübler, Arnulf

1991 Diffusion and long-term patterns and discontinuities. Technological Forecasting and Social Change 39:159-180.

Gurwitt, Rob

1998 The Comeback of the Cops. Governing. (January:14-19.

Kelling, George L. and Catherine M. Coles

1996 Fixing Broken Windows: Restoring Order and Reducing Crime in Our Communities. New York: Free Press.

Kelling, George L. and Mark H. Moore

1988 From Political to Reform to Community: The Evolving Strategy of Police. In Jack R. Greene and Stephen D. Mastrofski (eds.), Community Policing: Rhetoric or Reality. New York: Praeger.

Kelling, George L. and William H. Sousa, Jr.

2001 Do Police Matter? An Analysis of the Impact of New York City's Police Reforms. New York: Center for Civic Innovation at the Manhattan Institute.

Klockars, Carl B. and William E. Harver

1993 The Production and Consumption of Research in Police Agencies in the United States. Report to the National Institute of Justice. Newark: University of Delaware.

Law Enforcement News

1997 NYC's Compstat Continues to Win Admirers. (October 13):5.

Maas, Peter

1998 What We're Learning from New York City. Parade (May 10):4-6.

Manning, Peter K.

1997 Police Work: The Social Organization of Policing, 2d ed. Prospect Heights, Ill.: Waveland Press. 
Maple, Jack

1999 The Crime Fighter: Putting the Bad Guys Out of Business. New York: Doubleday.

Mastrofski, Stephen D.

1998 Community policing and police organization structure. In Jean-Paul Brodeur (ed.), How to Recognize Good Policing: Problems and Issues. Thousand Oaks, Calif.: Sage.

Mastrofski, Stephen D. and Robert C. Wadman

1991 Personnel and agency performance measurement. In William A. Geller (ed.), Local Government Police Management, 3d ed. Washington, D.C.: International City Management Association.

McDonald, Phyllis Parshall, Shelden Greenberg, and William Bratton 2001 Managing Police Operations: Implementing the NYPD Crime Control Model Using COMPSTAT. Belmont, CA: Wadsworth Publishing.

Melnicoe, William and Jan Minnig

1978 Elements of Police Supervision. Encino, Calif.: Glencoe Publishing Co.

Merton, Robert K.

1940 Bureaucratic Structure and Personality. Social Forces 18:560-568.

Micklethwait, John and Adrian Wooldridge

1996 The Witch Doctors: Making Sense of the. Management Gurus. New York: Random House.

Moore, Mark H.

1997 The Legitimation of Criminal Justice Policies and Practices. In National Institute of Justice, Perspectives on Crime and Justice: 1996-1997 Lecture Series. Washington, D.C.: U.S. Department of Justice.

Office of Management Analysis and Planning Undated The Compstat Process. New York: New York City Police Department.

Osborne, D. and T. Gaebler 1992 Reinventing Government. Reading, Mass.: Addison-Wesley.

Punch, Maurice

1983 Management, supervision and control. In Maurice Punch (ed.), Control in the Police Organization. Cambridge, Mass.: The MIT Press.

Remnick, David

1997 The Crime Buster. The New Yorker (February 24 and March 3):94-109.

Rogers, Everett M.

1995 Diffusion of Innovations. New York: Free Press.

Roth, Jeffrey, Joseph F. Ryan, Stephen J. Gaffigan, Christopher S. Koper, Mark H. Moore, Janice A. Roehl, Calvin C. Johnson, Gretchen E. Moore, Ruth M. White, Michael E. Buerger, Elizabeth A. Langston, and David Thacher

2000 National Evaluation of the COPS Program-Title I of the 1994 Crime Act. Washington, D.C.: National Institute of Justice.

Sayre, Wallace Stanley and Herbert Kaufman

1960 Governing New York City: Politics in the Metropolis. New York:

Russell Sage Foundation.

Selznick, Philip

1957 Leadership and Administration. New York: HarperCollins. 
Sherman, Lawrence W.

1990 Police crackdowns: Initial and residual deterrence. In Michael H. Tonry and Norval Morris (eds.), Crime and Justice: A Review of Research. Chicago: University of Chicago Press.

Sherman, Lawrence W. and David Weisburd

1995 General deterrent effects of police patrol in crime 'hot spots': A randomized controlled trial. Justice Quarterly 12:625-648.

Sherman, Laurence W., Denise Gottfredson, Doris MacKenzie, John Eck, Peter Reuter and Shawn Bushway

1997 Preventing Crime: What Works, What Doesn't, What's Promising? Washington, D.C.: U.S. Department of Justice, National Institute of Justice.

Silverman, Eli B.

1996 Mapping change: How the New York City Police Department reengineered itself to drive down crime. Law Enforcement News (December).

1999 NYPD Battles Crime: Innovative Strategies in Policing. Boston, Mass.: Northeastern University Press.

Simons, Robert

1995 Control in an age of empowerment. Harvard Business Review 73:1-7.

Skolnick, Jerome H. and David H. Bayley

1986 The New Blue Line: Police Innovations in Six American Cities. New York: Free Press.

Trojanowicz, Robert and Bonnie Bucqueroux

1990 Community Policing: A Contemporary Perspective. Cincinnati, Ohio: Anderson Publishing Company.

Weisburd, David and Anthony Braga

2003 Hot spots policing. In H. Kury and J. Obergfell-Fuchs (eds.), Crime Prevention: New Approaches. Manz: Weisser Ring

Weisburd, David and Thomas J. McEwen (eds.)

1997 Crime Mapping and Crime Prevention. Munsey: Criminal Justice Press.

Weisburd, David, Jerome McElroy, and Patricia Hardyman

1988 Challenges to supervision in community policing: Observations on a pilot project. American Journal of Police 7:29-50.

Weisburd, David, Orit Shalev, and Menachem Amir

2002 Community policing in Israel: Resistance and change. Policing: An International Journal of Police Strategies and Management 25: 80-109.

Weisburd, David, Stephen Mastrofski, Ann Marie McNally, and Rosann Greenspan 2001 Compstat and Organizational Change: Findings from a National Survey. Washington, D.C.: The Police Foundation.

Willis, James, Stephen D. Mastrofski, David Weisburd, and Rosann Greenspan 2003 Compstat and Organizational Change: Intensive Site Visits Report. Washington D.C.: Police Foundation.

Witkin, Gordon

1998 The crime bust. U.S. News and World Report (May 25):28-36. 
David Weisburd is Professor of Criminology at the Hebrew University Law School in Jerusalem and Professor of Criminology and Criminal Justice at the University of Maryland, College Park. He also serves as a Senior Fellow at the Police Foundation in Washington, DC.

Stephen Mastrofski is Professor of Public and International Affairs at George Mason University, where he is Director of the Administration of Justice Program and the Center for Justice Leadership and Management.

Ann Marie McNally received her MA from the School of Criminal Justice at Rutgers University and was a Research Associate at the Police Foundation when this research was conducted.

Rosann Greenspan, Ph.D. is Associate Director of the Center for the Study of Law and Society at the University of California, Berkeley, where she also teaches in the Legal Studies Program. Formerly she was Research Director of the Police Foundation.

James Willis is an Assistant Professor of Sociology at the University of Massachusetts Boston. 
